\title{
Sergius, the Paulician Leader, in the Account By Peter of Sicily*
}

\begin{abstract}
At the beginning of the second half of the ninth century, at the pinnacle of the Paulician power, Peter of Sicily resided on the territory of the Paulician state with the center in Tephrike (Tibrica, now Divrigi in Turkey) ${ }^{1}$, then under the protectorate of the Caliphate ${ }^{2}$. He was an official at the court of the Byzantine Emperor Basil I (867-886), who entrusted him with the negotiations on peace conditions and the exchange of prisoners ${ }^{3}$. During his mission Peter became interested in the beliefs of the Paulicians ${ }^{4}$. As he writes himself, he conducted a thorough investigation into the case ${ }^{5}$. He spent nine months among the Paulicians (at the turn of $869-870)^{6}$, which allowed him to collect a wealth
\end{abstract}

* This article has been written under the research project financed by the National Science Centre (Poland). Decision number: DEC-2016/22/M/HS3/00212 (Dualist Heresies in the History of South-East Europe, $9^{\text {th }}-15^{\text {th }}$ century).

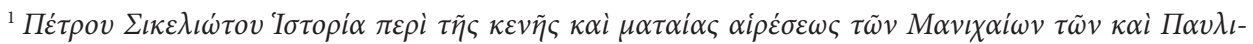

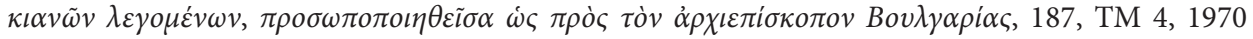
(cetera: Petrus Siculus, Istoría), p. 67. In Hamilton's translation: This happened in the second year of Basil, Constantine and Leo, our great pious and just emperor (Christian Dualist Heresies in the Byzantine World c. 650 - c. 1450, trans. et ed. J. Hamilton, B. Hamilton, Y. Stoyanov, Manchester 1998, p. 92).

${ }^{2}$ Petrus Siculus, Istoría, 4 and 187-188, p. 9 and 67.

${ }^{3}$ Petrus Siculus, Istoría, 4 and 187-188, p. 9 and 67. He wrote: I was among them on an imperial commission at the beginning of the reign of the autocrator Basil [...] My task concerned an exchange of prisoner (4, trans. Hamilton, p. 67) and: At that time I was in Tefrice, having been sent there in the imperial service to exchange some archons who were prisoners (187, trans. НАMILTON, p. 92). Tephrike is known as Abriq, Tafrīq or sometimes Al-Abrīq in Arabic sources (Hudūd al-älam, The Regions of the World, trans. V. MinORsky, Oxford 1937, p. 218).

${ }^{4}$ M. Tsibranska-Kostova (Paulicians Between the Dogme and the Legend, SCer 7, 2017) defines the terms 'Paulicianism' and 'Paulicians' as medieval heretics, followers of the dualistic teaching, which came to birth in Western Armenia in the $7^{\text {th }}$ century, and consequently, during the $8^{\text {th }}-10^{\text {th }}$ centuries, spread in Asia Minor, Syria, Byzantium, and Bulgaria.

${ }^{5}$ Petrus Siculus, Istoría, 5 , p. 9.

${ }^{6}$ I spent a period of about nine months there, while Basileius and Zosimus, their polluted so-called synekdemoi, were still alive (Petrus Siculus, Istoría, 188, p. 67, trans. НAmilton, p. 92). 
of first-hand information ${ }^{7}$. He emphasized that he had the opportunity to talk to many of the heretics, but he also talked to Orthodox Christians to learn as much as possible about the heresy. On this occasion, he learned that the Paulicians intended to send their missionaries to Bulgaria and decided to warn the head of the Bulgarian Church against the heretics by sending him a written account of their views, methods of action and leaders ${ }^{8}$. The addressee of this text, the Archbishop of Bulgaria, whom Peter named proedros ${ }^{9}$, was not mentioned by name. We can only suppose that we are talking about the first Orthodox archbishop of that country, appointed after Boris Mikhail, prince appointed by Godhad accepted Christianity ${ }^{10}$.

After recognizing the views of the Paulicians as Manichaean ${ }^{11}$, Peter used not only oral testimonies, but also the works of his predecessors, who fought the heresy of Mani. These included works by Cyril of Alexandria ${ }^{12}$, Socrates Scholasticus ${ }^{13}$ and Epiphanius of Cyprus ${ }^{14}$. He quoted the first of the above most extensively, however, supplementing the information with his own ${ }^{15}$. He also drew on the formula of renunciation of Manicheanism, which he quoted faithfully.

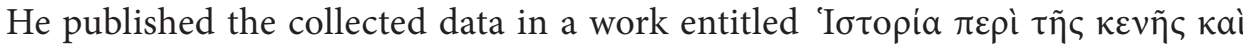

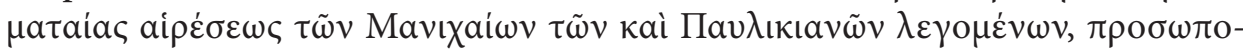

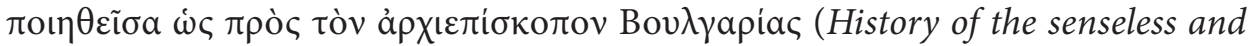
worthless heresy of the Manichaeans, also called the Paulicians, addressed to the Archbishop of Bulgaria). This text is considered to be the most competent source of information on both the history and doctrine of the Paulicians. Additional information can also be found in Peter's Speeches against the Manichaeans ${ }^{16}$. He discussed, among other things, the question of the existence of two Gods - the good and the bad - in the teaching of heretics, their attitude towards the Mother

\footnotetext{
${ }^{7}$ Peter boasted about his inquisitiveness: I made careful and precise enquiry about the matters aforesaid (Petrus Siculus, Istoría, 188, p. 67, trans. Hamilton, p. 92), I also made careful enquiries about them from the orthodox who lived there (Petrus Siculus, Istoría, 5, p. 9, trans. Hamilton, p. 67). ${ }^{8}$ Petrus Siculus, Istoría, 5 and 6, p. 9.

${ }^{9}$ Petrus Siculus, Istoría, p. 11 (Prologue).

${ }^{10}$ The first Orthodox archbishop was appointed after the baptism of Khan Boris in 864 (Chronographiae Quae Theophanis Continuati Nomine Fertur Liber Quo Vita Basilii Imperatoris Amplectitur, V, 96, ed. et trans. I. Sevcenko, Boston-Berlin 2011 (cetera: Theoph. Cont., Vita Basilii), p. 310-312). The first archbishop was in post by 870; see P. Lemerle (L'histoire des Pauliciens d'Asie Mineure d'après les sources grecques, TM 5, 1973, p. 21) for the dated epitaph of a member of his suite.

${ }^{11}$ Petrus Siculus, Istoría, 89, p. 39; 86, p. 37.

${ }^{12}$ Petrus Siculus, Istoría, 46, p. 23.

${ }^{13}$ Petrus Siculus, Istoría, 78, p. 35.

${ }^{14}$ Petrus Siculus, Istoría, 82-83, p. 37.

${ }^{15} 32$ fragments of his text (47-77) contain quotes from Cyril's Catechesis directed against Manicheans.

${ }^{16}$ Petrus Siculus, Adversus Manichaeos sermones tres, [in:] PG, vol. CIV, col. 1305-1349.
} 
of God, and the question of their rejection of the sacrament of communion. In unpreserved speeches, he considered their attitude towards the cross, the Old Testament, the prophets, Apostle Peter and the Orthodox Church. The above mentioned works are also known under the Latin titles: Historia Manichaeorum and Sermones contra manichaeos.

The texts of Peter of Sicily have survived in only one manuscript from the eleventh century (MS, Vat. gr. 511, ff. $80 \mathrm{v}-111 \mathrm{v})^{17}$, with its first and final parts destroyed. Of the six speeches against the Manichaeans, two have survived in their entirety, while the third is incomplete ${ }^{18}$. The History of the Manichaean Heresy was found by Jacques Sirmond in the Vatican Library and published in 1604 by the Jesuit Matthew Rader ${ }^{19}$. In 1847 Cardinal Angelo Mai, as the only publisher with access to MS Vat. gr. 511, published a slightly different version of this work ${ }^{20}$. We also owe him the publication of three speeches against the Manichaeans. Cardinal Mai's edition is the basis for a publication in Migne's Greek Patrology ${ }^{21}$. In 1849 Johann Karl Ludwig Gieseler published an abbreviated version of the work, attributed to Peter the Hegumenus ${ }^{22}$, believing that it was written by Peter of Sicily. We now have a new edition of the History of Manichaean Heresy, and its abbreviation ${ }^{23}$ thanks to the work of a group of researchers from the Centre de Recherche d'Histoire et Civilisation Byzantines in Paris.

A lot of information from Peter's works can be found in the treatise against the Manichaeans, written by Peter's contemporary Photius, Patriarch of Constantinople (858-867 and 877-886) ${ }^{24}$. The patriarch dedicated the first four books to the Paulicians. Although the relationships between the two authors are still under discussion, it seems that Peter was the first. R.M. Bartikian doubts that Peter and Photius wrote independently of each other, using another common source.

\footnotetext{
${ }^{17}$ M. Tsibranska-Kostova, Paulicians..., p. 234. The manuscript is discussed by R. Devresse (Codices Vaticani graeci, vol. II, Citta del Vaticano 1937, p. 364-367).

${ }^{18}$ J. Hamilton, B. Hamilton in Christian Dualist..., p. 66.

${ }^{19}$ Petri Siculi Historia ex ms. codice bibliothecae Vaticanae graece cum latina versione, ed. M. RADERUM, Ingolstadii 1604.

${ }^{20}$ A. MAI, Nova Bibliotheca Patrum, vol. IV.3, Roma 1837.

${ }^{21}$ Petrus Siculus, Historia utilis et refutatio atque eversio haeresos Manichaeorum qui et Pauliciani dicuntur, [in:] PG, vol. CIV, col. 1240-1349.

${ }^{22}$ Earlier J.K.L. Gieseler translated Peter's work and published it along with the text set by M. RADER: Petri Siculi Historia Manichaeorum sive Paulicianorum, textum Gr. M. Raderi, rec. L. Gieseler, Gottingae 1846.

${ }^{23}$ Les sources grecques pour l'histoire des pauliciens..., p. 1-226. Text and translation of the Istoría on pages 7-67.

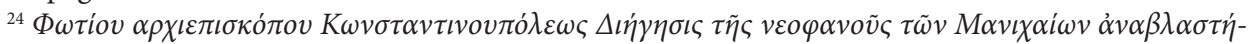
$\sigma \varepsilon \omega \varsigma$, (Diegesis), [in:] Les sources grecques pour l'histoire des pauliciens... (cetera: Рнотіus, Diegesis), p. 99-184. Older edition: Photıus, Contra Manichaeos libri quattor, [in:] PG, vol. CII, col. 15-264. On the date of composition see W. Treadgold, Photius Before His Patriarchate, JEH 53, 1, 2002, p. 8-9.
} 
Therefore, it should be assumed that the patriarch took information about the heresy of the Paulicians from Peter's History of the Manichaean Heresy ${ }^{25}$. Also later authors used works by Peter of Sicily. One of them was Euthymius Zygabenos, who knew and quoted them. The abbreviation of Peter's work made by Peter the Hegumenus was even more popular.

Peter of Sicily decided to present the views of the Paulicians briefly so that, as he wrote, it would be easy to remember them ${ }^{26}$. He then challenged them, trying to provide arguments to those who would combat them. We have neither time nor particular need to elaborate on the subject of Paulician theology ${ }^{27}$. I am going to disregard Peter's argument about the alleged continuity of heresy from Manicheanism to Paulicism, and the evolution as a result of which its followers were called Paulicians instead of Manicheans ${ }^{28}$. Suffice it to say that Peter explicitly stated that Paulicianism and Manichaeanism were one and the same heresy ${ }^{29}$.

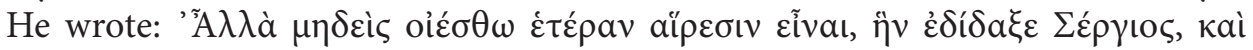

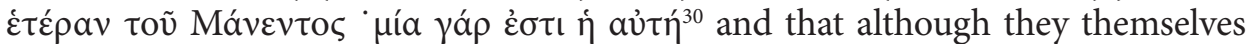
distanced themselves from Manicheism, in reality oủ yáp ă $\lambda \lambda$ oเ oữoเ kà ă $\lambda \lambda$ oเ

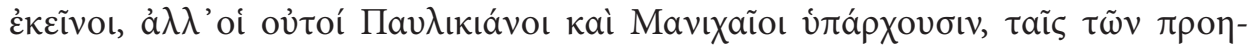

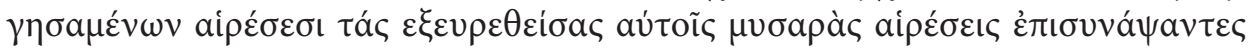

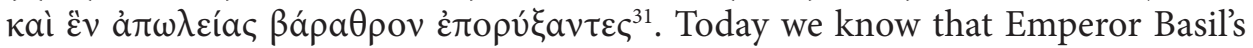
representative was wrong in identifying the Paulicians with the Manichaeans ${ }^{32}$.

${ }^{25}$ H. GréGoIre, Les sources de I'histoire des Pauliciens. Pierre de Sicile est authentique et «Photius» un faux, BCLSMP 22, 1936, p. 95-114; K. Ter-Mkrttschian, Die Paulikianer im byzantinischen Kaiserreiche und verwandte ketzerische Erscheinunge in Armenien, Leipzig 1893, p. 3-4, 9-14, 127.

${ }^{26}$ Petrus Siculus, Istoría, 35, p. 19.

${ }^{27}$ On Paulician religious beliefs see P. Lemerle, L'histoire des Pauliciens..., p. 126-132; M. Loos, Le mouvement paulicien de Byzance, II, Bsl 25, 1964, p. 55-63; P. CZARneCKI, Ewolucja doktryny radykalnego dualizmu w średniowieczu (VII-XIII wiek), PJAC 5, 2, 2013, p. 61-85; N.S. GARsoÏAN, Byzantine Heresy. A Reinterpretation, DOP 25, 1971, p. 94-113.

${ }^{28}$ Petrus Siculus, Istoría, 86, p. 37; 89, p. 39. Similarly in the title of the work.

${ }^{29}$ Petrus Siculus, Istoría, 170, p. 63.

${ }^{30}$ Petrus Siculus, Istoría, 170, p. 63. Let no one think that there are two different heresies, one taught by Sergius, the other by Mani; they are one and the same (trans. Hamilton, p. 89). At the same time Peter of Sicily states that the Paulicians called themselves "Christians" and their opponent Orthodox persecutors "Romans".

${ }^{31}$ Petrus Siculus, Istoría, 3, p. 9, trans. Hamilton, p. 66.

${ }^{32}$ There is no direct connection between the early teaching of Paul of Samosata and the later Paulician doctrine. See N.S. Garsoïan, The Paulician Heresy. A Study of the Origin and Development of Paulicianism in Armenia and the Eastern Provinces of the Byzantine Empire, The Hague-Paris 1967, p. 205; Eadem, Byzantine Heresy..., p. 95-96; M. Loos, Le mouvement..., II, p. 55-63; A. Nazmi, The Paulicians (Al-Bayāliqa) in Muslim Sources and Their Role in Wars between Arabs and Byzantines, SAI 9, 2001, p. 48; Д. РАДЕвА, Павликяни и павликянство в бблгарските земи (архетип и повторения VII-XVII век), София 2015, p. 58-65. Byzantine authors (Peter of Sicily, Euthymios Zigabenos, Anna Komnena) seemed to use the term of the Manichaeans in order to accuse Paulicians of being a dangerous and heterodox cult (H. Kusabu, Seminaries, Cults, and Militia in Byzantine Heresiologies. A Genealogy of the Labeling of "Paulicians", [in:] Radical Traditionalism. The Influence 
However, his opinions affected the perception of Paulicianism in Byzantium and Western Europe in the Middle Ages ${ }^{33}$.

Peter of Sicily pointed to the determination of the Paulicians - they were willing to accept many dangers and endure many blows in order to share their faith with those they met on their way. He had to see them as very convincing, since he considered it the best defense not to engage in debates with the Paulicians and avoid meetings with them. This was to apply in particular to simple people with no knowledge $e^{34}$. In his opinion, an ordinary man, out of concern for his safety, should avoid heretics like fire, because only people who know Scripture well are able to realize that they are dealing with heretics ${ }^{35}$. This is because the Paulicians, using allegory in a dishonest way, seem to accept all orthodox dogmas ${ }^{36}$. They loudly denounce Mani, Paul of Samosata and other heretics ${ }^{37}$, but they listen to even worse teachers and leaders ${ }^{38}$. They say one thing and mean another in their hearts, he says. They are like octopuses and chameleons - they change their shape to capture the victim. Only when somebody shows an interest in their teachings they gradually reveal their secrets ${ }^{39}$. They say that they listen to the words of the Gospel and the apostles, but they convey them cunningly and contrary to the truth $^{40}$. Reading these opinions it is impossible to resist the suspicion that Peter himself experienced serious difficulties during the disputes with leaders of the heresy in question.

In his account he devoted much space to the leaders of the Paulicians, starting with Constantine, also known as Saloanous, through Simeon, the emperor's envoy, who was tasked with fighting heretics but was eventually swayed by them.

of Walter Kaegi in Late Antique, Byzantine, and Medieval Studies, ed. C. Raffensperger, D. Olster, Lanham 2019 [= B.EEL], p. 187). It is worth mentioning that the idea of connecting Paulicians to Manichaeism is not reflected in Muslim sources (A. NAzmI, The Paulicians..., p. 45). The only exception is al-Mas údi who writes about their connection with dualism. Contrary to the Manichaeans the Paulicians were accepted and considered by the Muslims as their Christians subjects. See also A.R. Tayyara, Muslim-Paulician Encounters and Early Islamic Anti-Christian Polemical Writings, ICMR 27, 4, 2016, p. 471-489, available online: http://www.tandfonline.com/10.1080/09596410.2016. 1218650 [19 IX 2019].

${ }^{33}$ This thesis was repeated by other Byzantine authors, for example by Euthymios Zigabenos. According to Д. РАдевА (Павликяни и павликянство..., p. 58) Първият и основният източник за това изрично свгрзване на манихеите с павликяните е Петьр Сицилийски. In Byzantium civil laws and procedures against the heresy of Manichaeans had been applied to Paulician heresy (M. Tsibranska-Kostova, Paulicians..., p. 241; Ius Graecoromanum, vol. II, Leges imperatorum Isaurorum et Macedonum, ed. I. Zepos, P. Zepos, Athenis 1931, p. 219).

${ }^{34}$ Petrus Siculus, Istoría, 10 and 12, p. 11.

${ }^{35}$ Petrus Siculus, Istoría, 12, p. 11.

${ }^{36}$ Petrus Siculus, Istoría, 13, p. 11.

${ }^{37}$ Petrus Siculus, Istoría, 15, p. 13.

${ }^{38}$ Petrus Siculus, Istoría, 16, p. 13.

${ }^{39}$ Petrus Siculus, Istoría, 16, p. 13.

${ }^{40}$ Petrus Siculus, Istoría, 23, p. 15. 
Then Justus, Paul the Armenian and his two sons (Gegnesius, also called Timothy and Theodor), Zachariah, son of Gegnesius and his bastard Joseph, and finally Baanes, son of a pupil of Joseph ${ }^{41}$. Trying to discredit them, he emphasized that some of the worst heresy teachers came from the Saracens, some from slaves, others were born to prostitutes, and others took their mistakes from women ${ }^{42}$.

Sergius, known as the son of Druinus ${ }^{43}$ and as Tychicos ${ }^{44}$, had an important place among these figures. He was Greek ${ }^{45}$. He was brought up as an Orthodox Christian in a village Annia near Tabia (Tavium) in Galatia ${ }^{46}$ and received some education. We know that he wrote pastoral letters to the Paulician communities. Some of them are mentioned and even quoted by Peter of Sicily ${ }^{47}$. Later, Sergius was also credited with writing a commentary on the Gospel of St. Matthew ${ }^{48}$.

He began his activity during the reign of Empress Irene (797-802) and was the head of the community for 34 years (801-835) ${ }^{49}$. According to Peter, while still a young man, he had a relationship with a woman who was a Manichaean ${ }^{50}$ and

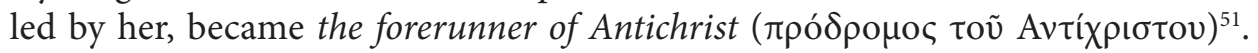
The woman read the Gospels, distorting the meaning of each sentence. Teaching

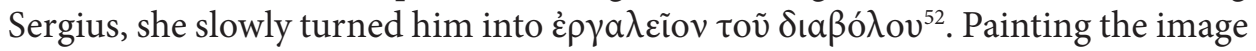
of the heresiarch with dark colors, Peter depicts him as a puppet in the hands of that woman. In the subsequent part of his account Peter calls Sergius viré $\rho$ -

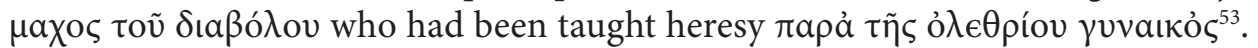
According to the interpretation of the Byzantine author, the devil himself used her in order to win over Sergius for heresy, suggesting him various questions and misinterpretation of texts ${ }^{54}$. It is worth noting that another tradition was known

\footnotetext{
${ }^{41}$ Petrus Siculus, Istoría, 130, p. 51; P. Lemerle, L'histoire des Pauliciens..., p. 69-70.

${ }^{42}$ Petrus Siculus, Istoría, 136, p. 53.

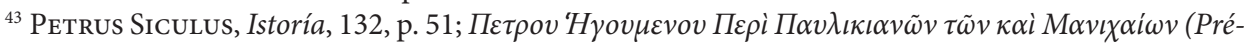
cis sur les pauliciens), 5-6, [in:] Les sources grecques pour l'histoire des pauliciens... (cetera: Petrus Igumenus), p. 82-83.

${ }^{44}$ Petrus Siculus, Istoría, 152, p. 57; Рнотius, Diegesis, 8-9, p. 123; 113, p. 159.

${ }^{45}$ J. Hamilton, B. Hamilton in Christian Dualist..., p. 19.

46 Д. РАДЕвА, Павликяни и павликянство..., p. 81; P. Lemerle, L'histoire des Pauliciens..., p. 70.

${ }^{47}$ Petrus Siculus, Istoría, 43, p. 21-23 and 158, p. 59. Their fragments were also found in Armenian text known as The Key of Truth (F.C. Conybeare, Introduction, [in:] The Key of Truth. A Manual of the Paulician Church in Armenia, ed. et trans. IDEm, Oxford 1898, p. XL-XLI). K. Ter-Mkrttschian, Die Paulikianer..., p. 22-24; P. Lemerle, L'histoire des Pauliciens..., p. 117-122.

${ }^{48}$ Le Synodikon de l'orthodoxie, ed. R. Gouillard, TM 2, 1967, p. 65.309-314 (trans. Hamilton, p. 137); J. Hamilton, B. Hamilton, Historical Introduction, [in:] Christian Dualist..., p. 19.

49 Д. РАДЕВА, Павликяни и павликянство..., p. 83.

${ }^{50}$ Petrus Siculus, Istoría, 138, p. 53; Photius, Diegesis, 101, p. 155; P. Lemerle, L'histoire des Pauliciens..., p. 116-117.

${ }^{51}$ Petrus Siculus, Istoría, 135, p. 53, trans. Hamilton, p. 83.

${ }^{52}$ Petrus Siculus, Istoría, 147, p. 57.

${ }^{53}$ Petrus Siculus, Istoría, 152, p. 57. In Hamilton's translation: the devil's champion, who had been taught her heresy by the destructive woman (p. 86).

${ }^{54}$ Petrus Siculus, Istoría, 138-146, p. 53-55.
} 
to later Byzantine writers, who claimed that the teacher of Sergius was a magician named Lycopetrus, or Peter the Wolf ${ }^{55}$. Sergius is mentioned also by Matthew of Edessa under the Armenian name, Sarkis and nickname Tychus (instead of Tichicus $)^{56}$.

The above characteristics contradicts the description of Sergius' achievements. As it was said he remained the leader of the Paulicians for thirty-four years, from the reign of Augusta Irene (797-802) until Emperor Theophilus (829-842). During that time he brought many people to apostasy, which Peter saw as the fulfillment of Apostle Paul's prophecy from the letter to the Thessalonians ${ }^{57}$. This was the result of the intense missionary activity of the Paulician leader. Sergius wandered tirelessly, visiting the cities and districts where Apostle Paul had taught eight hundred years earlier and, claiming to be his disciple, swayed many away from the Orthodox faith. Peter, who had access to his correspondence, claims that the heresiarch boasted of his successes in one of his letters ${ }^{58}$. The emperor's envoy was particularly hurt that there were many priests and Levites among the apostates, which proved the effectiveness of the Paulician propaganda. What is important, the apostasy turned out to be permanent, because during Peter's stay in Tephrike, the descendants of those converted by Sergius still followed heresy. The Byzantine had to admit that Sergius had caused significant damage to a large part of the Church of Christ ${ }^{59}$. He also could not ignore the fact that he enjoyed great esteem among the Paulicians and was even adored by his disciples as Paraclete and a Holy

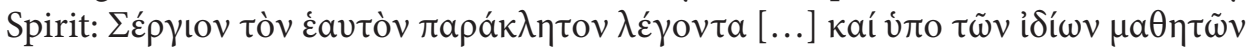
$\dot{\omega} \varsigma \pi v \varepsilon \tilde{v} \mu \alpha$ ă $\gamma t o v \pi \rho \circ \sigma \kappa v v o v ́ \mu \varepsilon v o v^{60}$. Peter sought to explain this popularity by the deceit committed by Sergius, who took the name of Tychikos (Tuxıкóv $\tau \varepsilon$

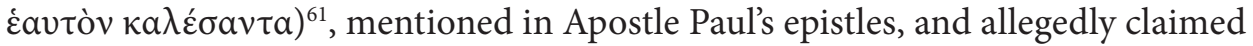
to be the Apostle's disciple, sent by him to teach. In Peter's opinion the devil's disciples often adopted new Christian names. The Sicilian also claims that the Paulician leader misrepresented the testimonies of Scripture, called himself Paraclete, and cunningly referred to the virtues and appearances of piety, hiding like a wolf in sheep's clothing. He did it so skilfully that many considered him a perfect

\footnotetext{
${ }^{55}$ Euthymii monachii Peribleptae Liber invectivus contra heresim exsecrabilium et impiorum haereticorum qui Phundagiatae dicintur, [in:] PG, vol. CXXXI, col. 47-58; trans. HAMILTon, p. 157 and 163-164 (the heretic Sergius and his dog).

${ }^{56}$ Eutyches in A.E. Dostourian's translation (The Chronicle of Matthew of Edessa, part II, 35, trans. et ed. A.E. Dostourian, Lanham-New York-London 1984, p. 113). F.C. Conybeare (Introduction..., p. LXVIII) gives the corrected version. See also S. Runciman, The Medieval Manichee. A Study of the Christian Dualist Heresy, Cambridge 1947, p. 36.

${ }^{57}$ 2Thess 2, 3.

${ }^{58}$ Petrus Siculus, Istoría, 153, p. 57.

${ }^{59}$ Petrus Siculus, Istoría, 154, p. 57.

${ }^{60}$ Petrus Siculus, Istoría, 134, p. 53; К. Ter-Mкrttschian, Die Paulikianer..., p. 22; Д. Радева, Павликяни и павликянство..., p. 51, 136.

${ }^{61}$ Petrus Siculus, Istoría, 134, p. 53.
} 
guide to salvation ${ }^{62}$, although he actually rejected piety. Peter considers people who succumbed to the teachings of Sergius to be ignorant, without giving any further thought to the reasons why the heresiarch was so successful. Judging the consequences of his actions, he observes that he did not teach the word of God, but a mortal error ${ }^{63}$, and that those who followed him were deprived eternal life and led to perdition.

Our author maintains that the heresiarch sought to destroy all men who professed pure faith, who were true Christians. The accusations made against Sergius are reminiscent of those made against the leaders of religious sects today. The heresiarch is said to have deterred the disciples of his faith from worldly life, alienated them from their families and led to their premature death ${ }^{64}$.

Among the evil deeds of the Paulician leader, selling Christian children was particularly horrible. Peter says that the heresiarch, with the help of his disciples, took children away from their parents and sold them in captivity to the Saracen barbarians ${ }^{65}$. The same fate befell handsome young men and women. The Sicilian paints a vivid image of infants torn away from the breasts of their mothers, brothers and sisters separated from their loved ones, driven out of their own country and sent to distant, alien places. According to the information available to him, many people died in bonds and in prison because of Sergius' actions, and others, who were rich, became destitute because of him ${ }^{66}$.

Other allegations concern violations of Christian morality. The heresiarch and his disciples allegedly broke up marriages and defiled marriage beds. Victims of their activity were monks taken from the monastic life and nuns who offered their virginity to $\mathrm{Christ}^{67}$.

Peter also learned that Sergius had a rival, a certain Baanes ('Vahan' in Armenian $)^{68}$. In fact, Baanes was the predecessor of Sergius ${ }^{69}$. He was born in Armenia and according to Photius he had a Jewish father. He later joined Epaphroditus in Antioch in Pisidia and eventually replaced him as a didaskalos ${ }^{70}$. Sergius, whose followers had always referred to Baanes as the "Reeking One", spoke against him ${ }^{71}$. According to Peter, there was an open confrontation between them, two or three times. Sergius, pretending to be godly, attacked Baanes in the

\footnotetext{
${ }^{62}$ Petrus Siculus, Istoría, 149, p. 57.

${ }^{63}$ Petrus Siculus, Istoría, 152, p. 57.

${ }^{64}$ Е.Э. Липшиц, Павликианское движение в Византии в VIII и первой половине IX вв., ВВ 5, 1952, p. 55-56.

${ }^{65}$ Petrus Siculus, Istoría, 154, p. 57.

${ }^{66}$ Petrus Siculus, Istoría, 155, p. 59.

${ }^{67}$ Petrus Siculus, Istoría, 154, p. 57-59; Д. РАДевА, Павликяни и павликянство..., p. 141.

${ }^{68}$ Petrus Siculus, Istoría, 170, p. 63.

${ }^{69}$ Baanes was at the head of the Paulicians from 777 or 783 to 801 . A. NAzmI, The Paulicians..., p. 48;

Д. РАДЕВА, Павликяни и павликянство..., р. 83, 140.

${ }^{70}$ J. Hamilton, B. Hamilton, Historical Introduction..., p. 18. Baanes died in 801.

${ }^{71}$ Petrus Siculus, Istoría, 170-172, p. 63-65.
} 
presence of all, accusing him not of matters of faith, but of unspecified acts of wickedness ${ }^{72}$. This led to an open conflict between the two men and to a schism in heresy ${ }^{73}$. Sergius was accepted as a didaskalos by some Paulicians, and it was then that he took the name Tychikos, whom St. Paul described as a beloved brother and faithful minister in the Lord ${ }^{74}$. It is not known what happened to Baanes, except that some of the Paulicians remained faithful to him. Even after Sergius' death, his disciples killed Baanes' followers ${ }^{75}$ until they were stopped by Theodot, Sergius' synekdemos, urging them to remain united ${ }^{76}$.

The role played by Sergius in the development of Paulician heresy and the esteem he enjoyed among them are evidenced by the epithets bestowed on him

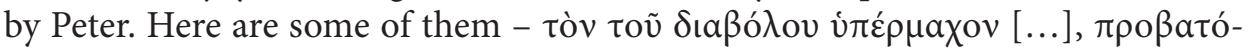

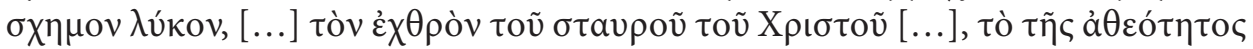

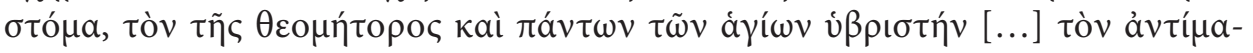

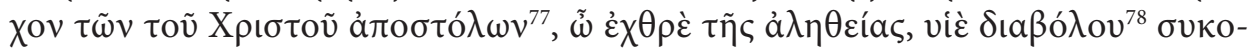

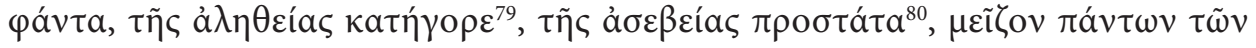

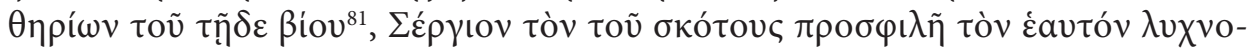

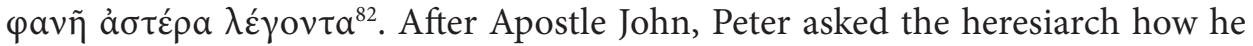
dared making himself equal to $\mathrm{God}^{83}$.

The terms used by Peter to describe Sergius correspond to the invectives

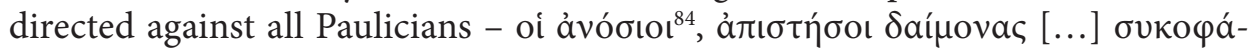

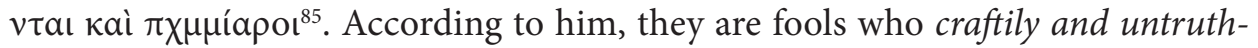
fully conceal the wolf under the sheepskin ${ }^{86}$.

The successes of Sergius drew the Emperor's attention to the Paulicians. While in the early days of his activity the Paulicians enjoyed relative tolerance, later the Patriarch Nicephoros (806-815) persuaded the ruler to recognize them as

\footnotetext{
${ }^{72}$ Petrus Siculus, Istoría, 170, p. 63.

${ }^{73}$ Petrus Siculus, Istoría, 172, p. 65; Photius, Diegesis, 125, p. 163; 128-129, p. 165; S. Runciмал, The Medieval Manichee..., р. 36; Д. РАдевА, Павликяни и павликянство..., p. 141-144; P. Lemerle, L'histoire des Pauliciens..., p. 80.

${ }^{74}$ Eph 6, 21.

${ }^{75}$ Petrus Siculus, Istoría, 173, p. 65; Рнотіus, Diegesis, 130, p. 165, 167; M. Loos, Le mouvement paulicien de Byzance, I, Bsl 24, 1963, p. 279.

${ }^{76}$ Petrus Siculus, Istoría, 174, p. 65; M. Loos, Le mouvement..., I, p. 279.

${ }^{77}$ Petrus Siculus, Istoría, 133, p. 51.

${ }^{78}$ Petrus Siculus, Istoría, 162, p. 61.

${ }^{79}$ Petrus Siculus, Istoría, 165, p. 61.

${ }^{80}$ Petrus Siculus, Istoría, 168, p. 63.

${ }^{81}$ Petrus Siculus, Istoría, 181, p. 65.

${ }^{82}$ Petrus Siculus, Istoría, 134, p. 53. The lover of darkness who called himself the star of daybreak (trans. HAMilton, p. 83).

${ }^{83}$ Io 5, 18; Petrus Siculus, Istoría, 162, p. 61.

${ }^{84}$ Petrus Siculus, Istoría, 5, p. 9.

${ }^{85}$ Petrus Siculus, Istoría, 34, p. 19.

${ }^{86}$ Petrus Siculus, Istoría, 23, p. 15, trans. Hamilton, p. 69.
} 
heretics and to take action against them. Michael I (811-813) and his successor, Leo V (813-820), seeing that heresy had attracted many Christians, ordered the death penalty for those who were involved in it $^{87}$. The orders of the emperor were executed, among others, by Bishop of Neocaesarea and exarch Paracondacus ${ }^{88}$. On this basis we can conclude that Sergius resided in the Neocaesarea area, probably in Kynochorion ${ }^{89}$.

The repressions were met with strong resistance from the Paulicians. Sergius' disciples, called astatoi, cunningly and treacherously murdered the exarch, while the inhabitants of Cynochoritae killed metropolitan Thomas ${ }^{90}$. Astatoi, who became the military arm of the Paulicians, fled to Melitene ${ }^{91}$, to Muslim-controlled areas. The local emir, Monocherares - 'One-Handed', that is 'Umar Ibn 'Abd Allāh al-Aqța' (about 830-863), gave the astatoi the fortress Argaoun (today Arguvan) ${ }^{92}$. Various Muslim authors (eg. Al-Mas ūdī, Aț-Ṭabarī and Ibn al-Atīr) indicate that an alliance might have existed between Paulicians and the Arabs ${ }^{93}$.

${ }^{87}$ Petrus Siculus, Istoría, 175, p. 65; Theophanes AM 6304, p. 495; P. Lemerle, L'histoire des Pauliciens..., p. 81. The author of Vita Macarii writes about punishing the Paulicians with death during the times of Emperor Theophilus (S. Macarii monasterii Pelecetes hegumeni acta graeca, 14, ed. H. Delehaye, AB 16, 1897, p. 159). George the Monk accused the emperor Constantin V of favoring the Paulicians (Georgius Monachus, Chronicon, vol. II, ed. C. DE Boor, Leipzig 1904, p. 752). According to some scholars, the Paulicans previously collaborated with the iconoclast emperors (N.S. Garsoïan, The Paulician Heresy..., p. 122-123; Д. РАдевА, Павликянството между тегендите и историята VII-XVII век, ПИФ 1, 2, 2017, p. 42-43, online: https://logos.uni-plovdiv.net/en/elektronno-spisanie-plovdivski-istoriceski-forum [19 IX 2019]; Д. РАДЕвА, Павликяни и павликянство..., p. 80-81; M. Loos doubts such cooperation (Le mouvement..., I, p. 267-268). Also Emperor Nicephorus I (802-811) was designated by Theophanes as an ardent friend of the Manicheans, i.e. Paulicians (Theophanis Chronographia, AM 6303, ed. C. DE Boor, Leipzig 1883 (cetera: Theophanes), p. 488.

${ }^{88}$ Petrus Siculus, Istoría, 176, p. 65.

${ }^{89}$ P. Lemerle, L'histoire des Pauliciens..., p. 71.

90 Д. РАдевА, Павликяни и павликянство..., p. 84; P. Lemerle, L'histoire des Pauliciens..., p. 72.

${ }^{91}$ Petrus Siculus, Istoría, 177, p. 65; A. Nazmi, The Paulicians..., p. 48, 54; Е.Э. Липшиц, Павликианское..., р. 57; Д. РАДевА, Павликянството..., p. 44; P. Lemerle, L’histoire des Pauliciens..., p. 72-73, 82. On 'Umar Ibn 'Abd Allāh al-Aqța' see M. CANARD, Un personnage de roman arabo-byzantin, [in:] IDEM, Byzance et les musulmans de Proche Orient, praef. C. CAHEN, London 1973, p. 1-14. On Melitena - E. Honigman, Malatya, [in:] The Encyclopedia of Islam, vol. VI, Leiden 1991, p. 230-231.

${ }_{92}$ They also settled around Tephrike and Amara (Theophanis Continuati libri I-IV, IV, 16, ed. et trans. M. Featherstone, J. Signes Codoñer, Boston-Berlin 2015 [= CFHB, 53] (cetera: Theoph. ConT.), p. 236).

${ }_{93}$ The war with the Byzantine Empire was also recorded in Arabic poetry, in folk epics like the story of Dāt al-Himma and in Byzantine epic Digenis Akritas. For the details see S.B. Dadoyan, The Armenians in the Medieval Islamic World. Paradigms of Interaction Seventh to Fourteenth Centuries, vol. I, The Arab Period in Arminjah: Seventh to Eleventh Centuries, New Brunswick-London 2013, p. 96-107; A. Nazmi, The Paulicians..., p. 54-58; G. Huxley, Antecedents and Context of Digenes Akrites, GRBS 15, 1974, p. 317-338. 
Muslim caliphs had generally offered Paulicians hospitable shelter because they were the main enemy of the Byzantines and knew the region well, and thus could serve as guides during the Muslim marches against Byzantines, actively participating in wars against the Byzantium ${ }^{94}$. That was the reason why the Paulicians enjoyed a kind of autonomy under the 'Abbasids ${ }^{95}$. Having settled there and gathered supporters from all sides, the Paulicians started attacking the empire arm in arm with the Arabs ${ }^{96}$. The chronology of these events is uncertain. It is possible that it took place during the rebellion of Thomas the Slav - in the $820 \mathrm{~s}^{97}$. Then Sergius and many of his followers joined the astatoi in Argaoun. Sergius, who made a living as a carpenter, lived there for some time with his disciples, without giving up his missionary activity.

The Paulician leader founded new communities, naming them after the first Christian communities founded by Apostle Paul ${ }^{98}$. This is how the Paulician "Colossan" Church came into being (which brought together the inhabitants of Cynochoritae) $)^{99}$ and the Church of the "Laodiceans". The latter was founded when Sergius moved his headquarters to Kynochorion near Neocaesarea (Niksar). His activity was not confined to the regions mentioned above. During his mission to Cilicia he founded, probably with the consent of Emir of Tarsus, the Church of the "Ephesians" based in Mimistra ${ }^{100}$.

Sergius died a violent death, slaughtered with an axe in the mountains above Argaoun by a man named Tzanion, who came from a kastellon in the Nicopolis region ${ }^{101}$. It happened in the year 6343 since the foundation of the world

\footnotetext{
${ }^{94}$ A. Nazmi, The Paulicians..., p. 50-51; Д.О. Ловвский, Д.А. Никульшин, К вопросу об ереси павликиан в Византии, ИУГУ 33, 2004, p. 208; S.B. Dadoyan, The Armenians..., vol. I, The Arab Period..., p. 45-46, 95-101; vol. II, Armenian Realpolitik in the Islamic World and Diverging Paradigms Case of Cilicia: Eleventh to Fourteenth Centuries, New Brunswick-London 2013, p. 10-11, 40. ${ }^{95}$ A. Nazmi, The Paulicians..., p. 54.

${ }^{96}$ Petrus Siculus, Istoría, 178, p. 65; Photius, Diegesis, 138, p. 169; H. Kennedy, The Prophet and the Age of the Caliphates. The Islamic Near East from the Sixth to the Eleventh Century, London 1986, p. 152-154; P. Sophoulis, Byzantium and Bulgaria, 775-831, Leiden-Boston 2012, p. 249; N.S. GARsoïan, The Paulician Heresy..., p. 120, 135; F. AlPI, Messaggi attraverso il confine: l'Armenia e il confine orientale di Bisanzio nelle Lettere di Grigor Pahlawowni Magistros (ca. 990-1058) (Diss., Università di Pisa 2014, available online: https://core.ac.uk/download/pdf/79619043.pdf, 19 IX 2019), p. 223, 243 (i pauliciani avevano fatto fronte comune con gli Arabi).

${ }^{97}$ J. Намilton, В. Наміlтon, Historical Introduction..., p. 20; Д. РАДЕвА, Павликяни и павликянство..., p. 81.

${ }^{98}$ Petrus Igumenus, 7, p. 84; M. Tsibranska-Kostova, Paulicians..., p. 239; P. Lemerle, L'histoire des Pauliciens..., p. 118-120.

${ }^{99}$ Petrus Igumenus, 7, p. 84; N.S. Garsoïan, The Paulician Heresy..., p. 119.

${ }^{100}$ Petrus Igumenus, 7, p. 84; Photius, Diegesis, 139-140, p. 169; S. Runciman, The Medieval Manichee..., p. 39; J. НаміlтоN, В. НаміlтоN, Historical Introduction..., p. 20; Д. РАдевА, Павликяни и павликянство..., p. 83-84.

${ }^{101}$ Petrus Siculus, Istoría, 180, p. 65; P. Lemerle, L’histoire des Pauliciens..., p. 74.
} 
$(=\mathrm{AD} 834 / 835)^{102}$. The reasons for this crime are unknown. It should not come as a surprise that, according to Peter, it was God's punishment for dividing the Church $^{103}$.

The protagonist of this paper prepared the community well for further fights with Byzantium and dealing with their Saracen neighbors. He also introduced changes to Paulician theology ${ }^{104}$. In the opinion of contemporary researchers, Sergius was dernier grand docteur paulicien ${ }^{105}$, the great Paulician apostle ${ }^{106}$, greater heresiarch ${ }^{107}$ and a person of great charisma. He demonstrated more pleasing morals, good manners and tenderness than his predecessor, Baanes ${ }^{108}$. He is not, however, un grand théologien but rather un homme d'action ${ }^{109}$.

His work was continued by a large group of disciples, among whom Peter mentions Michael, Canacharis, John Aoratus (who he calls false priests), Theodot, Basileius, Zosimus and others ${ }^{110}$. While Peter was in Tephrike, Basileius and Zosimus were still alive ${ }^{111}$ and were religious leaders. Their names, along with the name of Sergius, were among those condemned in anathemas ${ }^{112}$.

Those disciples whom the Paulicians called companions of the road (synekdemoi, $\sigma v v \varepsilon ́ \kappa \delta \eta \mu \mathrm{o}$ ), after the death of their teacher, disseminated his teachings and those of his predecessors among the residents of Argaoun. According to the information provided to Peter, at first they did not choose one leader, but they all had the same rank, they were all equal. They had subordinates, whom they called notaries (votápıot) ${ }^{113}$, who, according to Peter, were false priests. It seems that the synekdemoi maintained their position also when the Paulicians were joined by

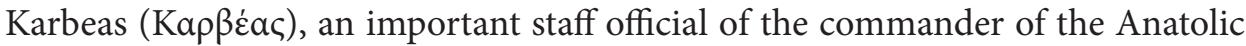
Theme, who rebelled after the execution of his father, fled to Argaoun with a group of Paulicians (they were said to have been five thousand) and offered his services

\footnotetext{
${ }^{102}$ Petrus Siculus, Istoría, 181, p. 65; Д. РАдевА, Павликяни и павликянство..., p. 84; Е.Э. ЛиПшиц (Павликианское..., p. 58) wrote that Смерть Сергия отнесена Петром Сицилийцем к 6303 г. от сотворения мира, что соответствует у Фотия 6343 г., т. е. если следовать общепринятой константинопольской эре, по Петру событие это относится к 795 г., по Фотию же - 8352 .

${ }^{103}$ Petrus Siculus, Istoría, 179, p. 65.

${ }^{104}$ N.S. Garsoïan, The Paulician Heresy..., p. 182-185; EAdEм, Byzantine Heresy..., p. 96; Д. РАДЕВА, Павликяни и павликянство..., p. 101, 117-118, 141, 157.

${ }^{105}$ Le Synodikon de l'orthodoxie..., p. 133.

${ }^{106}$ F.C. CONybeare, Introduction..., p. XXXII.

${ }^{107}$ S. Runciman, The Medieval Manichee..., p. 35.

108 Д. РАДЕвА, Павликяни и павликянство..., p. 141.

${ }^{109}$ P. Lemerle, L'histoire des Pauliciens..., p. 122.

${ }^{110}$ Petrus Siculus, Istoría, 182, p. 67.

${ }^{111}$ Petrus Siculus, Istoría, 187, p. 67.

${ }^{112}$ Les formules d'abjuration, I, 15; II, 14; III, 2; IV, 9, [in:] Les sources grecques pour l'histoire des pauliciens..., p. 193, 195, 197, 199, 205, 207; J. Goulllard, Commentaire..., p. 233-234.

${ }^{113}$ Petrus Siculus, Istoría, 183, p. 67; K. Ter-Mkrttschian, Die Paulikianer..., p. 26-27.
} 
to the Emir of Melitena ${ }^{114}$. During his time, the numbers and power of the Paulicians grew. They left Argaoun, founded Tephrike and settled there before $856^{115}$.

As a result, they became partially independent from the Muslims of Melitena, and living in the vicinity of Armenia and Byzantium they were able to attack them ${ }^{116}$. They subjugated the local population, using those who obeyed them as helpers in guarding the prisoners. The disobedient were sold to Saracens. Karbeas made Tephrike a shelter for those who were sentenced to death for Paulician heresy in the empire ${ }^{117}$. Also supporters of heresy from the vicinity of Tephrike gathered here. According to Peter, they were the most greedy, the most promiscuous and insane people, tempted by the promise of freedom to fulfill their most shameful desires ${ }^{118}$.

The mission of Peter of Sicily in Tephrike ended in failure, so in the following years Basil I undertook campaigns against the Paulicians and despite initial setbacks he managed to defeat them and destroyed Tephrike $(871 / 872)^{119}$. However, the ruler decided not to persecute the defeated, but to use their military potential, eagerly conscripting them into the ranks of the Byzantine army. Almost one hundred years earlier in 757, the Paulician colony was founded in Thrace by Emperor Constantine $\mathrm{V}^{120}$. John Tzimiskes (969-976) resettled them in the vicinity of Philippopolis, a fortress that he had recently taken away from the Bulgarians ${ }^{121}$. Thus, although in a different way than envisaged by Peter of Sicily, the Paulicians found themselves in the Bulgarian territory. The Bulgarian clergy already had the right materials to meet that challenge.

\footnotetext{
${ }^{114}$ Karbeas is called Qarbiyās in Arabic sources (A. NAzmi, The Paulicians..., p. 53-55). On Karbeas see P. Lemerle, L'histoire des Pauliciens..., p. 856-896.

${ }^{115}$ Е.Э. ЛиПшиц, Павликианское..., р. 59; Д. РАдевА, Павликянството..., p. 45.

${ }^{116}$ Petrus Siculus, Istoría, 184, p. 67; S. Runciman, The Medieval Manichee..., p. 39-44; Д. РАдевА, Павликяни и павликянство..., p. 85.

${ }^{117}$ Theoph. Cont., IV, 16, p. 237-139; IV, 23, p. 250-252; Theoph. Cont., Vita Basilii, 37-43, p. 136-159 (= ed. I. BEKKER, p. 165-166; 176-177, V, 37-43, 266-276); Iosephi Genesii Regum libri quattuor, I, 31; I, 34-37, rec. A. LesMueller-Werner, Berolini 1978 [= CFHB, 14], p. 81-82, 85-88 (= ed. C. LaChmann, Bonn 1834 [= CSFB], p. 120-126); Georgii Cedreni Historiarum Compendium, vol. II, ed. I. BeккER, Bonn 1839 [= CSHВ], p. 206-212; Д. РАДЕвА, Павликяни и павликянство..., p. 85; P. Lemerle, L'histoire des Pauliciens..., p. 92-96.

${ }_{118}$ Petrus Siculus, Istoría, 185, p. 67.

${ }_{119}$ A. Nazmi, The Paulicians..., p. 59; Д.О. Ловвский, Д.А. Никульшин, К вопросу..., p. 208; W.M. Ramsay, The Campaign of Basil I. against the Paulicians in 872 AD, CR 10, 1896, p. 136-140; Д. РАДЕвА, Павликянството..., p. 45-46; P. Lemerle, L'histoire des Pauliciens..., p. 104-110.

${ }^{120}$ Theophanes, AM 6247, p. 429; A. Nazmi, The Paulicians..., p. 59; Y. Stoyanov, The Other God. Dualist Religions from Antiquity to the Cathar Heresy, New Haven 2000, p. 150; P. Charanis, The Transfer of Population as a Policy in the Byzantine Empire, CSSH 3, 2, 1961, p. 140-154; S. Runciman, The Medieval Manichee..., p. 39.

${ }^{121}$ Crisi, rotture e cambiamenti, ed. U. Bianchi et al., Milano 1995, p. 197; Christian Dualist..., p. 23; M. Tsibranska-Kostova, Paulicians..., p. 232; Р.М. БАртикян, Византийская, армянская и болгарская легенды о происхождении павликиан и их историческая основа, BBg 6, 1980, p. 61; Н. KusAbU, Seminaries..., p. 183; Д.О. ЛоввСКий, Д.А. Никульшин, К вопросу..., р. 209.
} 


\section{Bibliography}

\section{Primary Sources}

\section{Editions and translations of the texts of Peter of Sicily}

Peter of Sicily's History of the Paulicians, [in:] Christian Dualist Heresies in the Byzantine World c. 650 - c. 1450, trans. et ed. J. Hamilton, B. Hamilton, Y. Stoyanov, Manchester 1998, p. 65-92.

Petri Siculi Historia ex ms. codice bibliothecae Vaticanae graece cum latina versione, ed. M. RADERUM, Ingolstadii 1604.

Petri Siculi Historia Manichaeorum, ed. A. MAI, [in:] Nova Bibliotheca Patrum, vol. IV.3, Roma 1837, p. 1-47.

Petri Siculi Historia Manichaeorum sive Paulicianorum, textum Gr. M. RAderI, rec. L. Gieseler, Gottingae 1846.

Petri Siculi Sermones adversus Manichaeos, ed. A. MaI, [in:] Nova Bibliotheca Patrum, vol. IV.3, Roma 1837, p. 48-79.

Petrou Sikeliou Istoria peri tes kenes kai mataias haireseos ton Manichaion kai Paulikianon legomenon, prosopopoietheisa hos pros ton archiepiskopon Boulgarias, "Travaux et mémoires du Centre de recherches d'histoire et civilisation byzantines" 4, 1970 (= Les sources grecques pour l'histoire des pauliciens d'Asie Mineure, ed. C. Astruc, W. Conus-Wolska, J. Guillard, P. Lemerle, D. Papachryssanthou, J. Paramelle), p. 7-67.

Petrus Siculus, Adversus Manichaeos sermones tres, [in:] Patrologiae cursus completus, Series graeca, vol. CIV, ed. J.-P. Migne, Paris 1860, col. 1305-1349.

Petrus Siculus, Historia utilis et refutatio atque eversio haeresos Manichaeorum qui et Pauliciani dicuntur, [in:] Patrologiae cursus completus, Series graeca, vol. CIV, ed. J.-P. Migne, Paris 1860, col. 1240-1304.

"Poleznaja istorija" Petra Sicilijskogo, trans. R.M. Bartikjan, [in:] R.M. Bartikjan, Petr Sicilijskij i ego "Istorija pavlikian", “Византийский временник" / "Vizantijskij vremennik” 18, 1961, p. 330-358 (= "Poleznaja istorija” Petra Sicilijskogo - osuždenie i oproverženie eresi manicheev, nazyvaemych takže pavlikianami, načertannaja dlja archiepiskopa Bolgarii, trans. R.M. BARTIKJAN, [in:] Istočniki dlja izučenija istorii pavlikianskogo dviženija, Erevan 1961, p. 117-151).

\section{Editions and translations of the text of Peter the Igumenos}

Peter the Higoumenos, An Abridgement of Peter of Sicily, [in:] Christian Dualist Heresies in the Byzantine World c. 650 - c. 1450, trans. et ed. J. Hamilton, B. Hamilton, Y. Stoyanov, Manchester 1998, p. 92-96.

Petrou Hegoumenou Peri Paulikianon ton kai Manichaion (Précis sur les pauliciens), "Travaux et mémoires du Centre de recherches d'histoire et civilisation byzantines" 4, 1970 (= Les sources grecques pour l'histoire des pauliciens d'Asie Mineure, ed. C. Astruc, W. Conus-Wolska, J. Guillard, P. Lemerle, D. Papachryssanthou, J. Paramelle), p. 69-97. 


\section{Editions and translations of the text of Photius}

Fotiou archiepiskopou Konstantinoupoleos Diegesis tes neofanous ton Manichaion anablasteseos (Diegesis), "Travaux et mémoires du Centre de recherches d'histoire et civilisation byzantines" 4, 1970 (= Les sources grecques pour l'histoire des pauliciens d'Asie Mineure, ed. C. Astruc, W. Conus-Wolska, J. Guillard, P. Lemerle, D. Papachryssanthou, J. Paramelle), p. 99-184.

Pнотіus, Contra Manichaeos libri quattor, [in:] Patrologiae cursus completus, Series graeca, vol. CII, ed. J.-P. Migne, Paris 1900, col. 15-264.

\section{Other}

The Chronicle of Matthew of Edessa, trans. et ed. A.E. Dostourian, Lanham-New York-London 1984.

Chronographiae Quae Theophanis Continuati Nomine Fertur Liber Quo Vita Basilii Imperatoris Amplectitur, ed. et trans. I. Sevcenko, Boston-Berlin 2011 (= Theophanes Continuatus, Chronographia, [in:] Theophanes Continuatus, Ioannes Cameniata, Symeon Magister, Georgius Monachus, ed. I. BEKKER, Bonn 1838 [= Corpus scriptorum historiae byzantinae, 31], p. 1-481).

Euthymii monachii Peribleptae Liber invectivus contra heresim exsecrabilium et impiorum haereticorum qui Phundagiatae dicintur, [in:] Patrologiae cursus completus, Series graeca, vol. CXXXI, ed. J.-P. Migne, Paris 1864, col. 47-58.

Euthymius of the Periblepton, A Letter from Euthymius, Monk of the Monastery of the Periblepton Sent [...] to His Native Land, trans. J. Hamilton, B. Hamilton, [in:] Christian Dualist Heresies in the Byzantine World c. 650 - c. 1450, trans. et ed. J. Hamilton, B. Hamilton, Y. Stoyanov, Manchester 1998, p. 143-164.

Les formules d'abjuration, "Travaux et mémoires du Centre de recherches d'histoire et civilisation byzantines" 4, 1970 (= Les sources grecques pour l'histoire des pauliciens d'Asie Mineure, ed. C. Astruc, W. Conus-Wolska, J. Guillard, P. Lemerle, D. Papachryssanthou, J. ParaMELLE), p. 191-207.

Georgii Cedreni Historiarum Compendium, vol. II, ed. I. BeKker, Bonn 1839 [= Corpus scriptorum historiae byzantinae].

Georgius Monachus, Chronicon, vol. II, ed. C. DE Boor, Leipzig 1904.

Iosephi Genesii Regum libri quattuor, rec. A. LeSMUeller-Werner, Berolini 1978 [= Corpus fontium historiae byzantinae, 14] (= ed. C. LACHMANN, Bonn 1834 [= Corpus scriptorum historiae byzantinae]).

Ius Graecoromanum, vol. II, Leges imperatorum Isaurorum et Macedonum, ed. I. ZEPos, P. ZEPos, Athenis 1931 (= Aalen 1962).

S. Macarii monasterii Pelecetes hegumeni acta graeca, ed. H. Delehaye, "Analecta Bollandiana" 16, 1897, p. 140-163.

Le Synodikon de l'orthodoxie, ed. R. Gouillard, “Travaux et mémoires du Centre de recherches d'histoire et civilisation byzantines" 2, 1967, p. 1-316.

Theophanis Chronographia, vol. I, ed. C. DE Boor, Leipzig 1883, trans.: The Chronicle of Theophanes Confessor. Byzantine and Near Eastern History, AD 284-813, trans. C. MANGo, R. ScotT, G. Greatrex, Oxford 1997. 
Theophanis Continuati libri I-IV, ed. et trans. M. Featherstone, J. Signes Codoñer, Boston-Berlin 2015 [= Corpus fontium historiae byzantinae, 53] (= Theophanes Continuatus. Chronographia, [in:] Theophanes Continuatus, Ioannes Cameniata, Symeon Magister, Georgius Monachus, ed. I. BeKKeR, Bonn 1838 [= Corpus scriptorum historiae byzantinae, 31], p. 1-481).

\section{Secondary Literature}

Alpi F., Messaggi attraverso il confine: l'Armenia e il confine orientale di Bisanzio nelle Lettere di Grigor Pahlawowni Magistros (ca. 990-1058) (Diss., Università di Pisa 2014, available online: https://core.ac.uk/download/pdf/79619043.pdf, 19 IX 2019).

BARTIKJAn R.M., Vizantijskaja, armjanskaja i bolgarskaja legendy o proischoždenii pavlikian $i$ ich istoričeskaja osnova, "Byzantinobulgarica" 6, 1980, p. 57-62.

CANARD M., Un personnage de roman arabo-byzantin, [in:] M. CANARD, Byzance et les musulmans de Proche Orient, praef. C. CAHEN, London 1973, p. 1-14.

Charanis P., The Transfer of Population as a Policy in the Byzantine Empire, "Comparative Studies in Society and History" 3, 2, 1961, p. 140-154, available online: https://doi.org/10.1017/ S0010417500012 093 [19 IX 2019].

Conybeare F.C., Introduction, [in:] The Key of Truth. A Manual of the Paulician Church in Armenia, ed. et trans. F.C. Conybeare, Oxford 1898, p. XXIII-CXCVI.

Crisi, rotture e cambiamenti, ed. U. BIANCHI et al., Milano 1995.

CzArnecki P., Ewolucja doktryny radykalnego dualizmu w średniowieczu (VII-XIII wiek), "The Polish Journal of the Arts and Culture" 5, 2, 2013, p. 61-85.

Dadoyan S.B., The Armenians in the Medieval Islamic World. Paradigms of Interaction Seventh to Fourteenth Centuries, vol. I, The Arab Period in Arminjah: Seventh to Eleventh Centuries, vol. II, Armenian Realpolitik in the Islamic World and Diverging Paradigms Case of Cilicia: Eleventh to Fourteenth Centuries, New Brunswick-London 2013.

Devresse R., Codices Vaticani graeci, vol. II, Citta del Vaticano 1937.

Garsoïan N.S., Byzantine Heresy. A Reinterpretation, "Dumbarton Oaks Papers" 25, 1971, p. 85-113.

Garsoïan N.S., The Paulician Heresy. A Study of the Origin and Development of Paulicianism in Armenia and the Eastern Provinces of the Byzantine Empire, The Hague-Paris 1967.

Grégoire H., Les sources de I'histoire des Pauliciens. Pierre de Sicile est authentique et «Photius» un faux, "Bulletin de la Classe des lettres et des sciences morales et politiques" 22, 1936, p. 95-114.

Hamilton J., Hamilton B., Historical Introduction, [in:] Christian Dualist Heresies in the Byzantine World c. 650 - c. 1450, trans. et ed. J. Hamilton, B. Hamilton, Y. Stoyanov, Manchester 1998, p. $1-55$.

Honigman E., Malatya, [in:] The Encyclopedia of Islam, vol. VI, Leiden 1991, p. 230-231.

Huxley G., Antecedents and Context of Digenes Akrites, “Greek, Roman, and Byzantine Studies” 15, 1974, p. 317-338.

Kennedy H., The Prophet and the Age of the Caliphates. The Islamic Near East from the Sixth to the Eleventh Century, London 1986.

Kusabu H., Seminaries, Cults, and Militia in Byzantine Heresiologies. A Genealogy of the Labeling of "Paulicians", [in:] Radical Traditionalism. The Influence of Walter Kaegi in Late Antique, Byzantine, and Medieval Studies, ed. C. Raffensperger, D. Olster, Lanham 2019 [= Byzantium: A European Empire and Its Legacy], p. 181-196. 
Lemerle P., L'histoire des Pauliciens d'Asie Mineure d'après les sources grecques, "Travaux et mémoires du Centre de recherches d'histoire et civilisation byzantines" 5, 1973, p. 1-144.

LIPšıc E.È., Pavlikianskoe dviženie v Bizantii v VIII i pervoj polovine IX vv., "Византийский временник" / "Vizantijskij vremennik" 5, 1952, p. 49-72.

Loevskij D.O., Nikul’šın D.A., K voprosu ob eresi pavlikian v Vizantii, “Известия Уральского государственного университета" / "Izvestija Ural'skogo Gosudarstvennogo Universiteta” 33, 2004, p. 203-210.

Loos M., Le mouvement paulicien de Byzance, I, "Byzantinoslavica. Revue internationale des études byzantines" 24, 1963, p. 258-286; II, "Byzantinoslavica. Revue internationale des études byzantines" 25, 1964, p. 52-68.

Nazmi A., The Paulicians (Al-Bayāliqa) in Muslim Sources and Their Role in Wars between Arabs and Byzantines, "Studia Arabistyczne i Islamistyczne" 9, 2001, p. 44-60.

Radeva D., Pavlikjani i pavlikjanstvo v bălgarskite zemi (arhetip i povtorenija VII-XVII v.), Sofija 2015.

Radeva D., Pavlikjanstvoto meždu legendite i istorijata VII-XVII vek, “Пловдивски исторически форум" / "Plovdivski istoričeski forum" 1, 2, 2017, p. 36-57, available online: https://logos. uni-plovdiv.net/en/elektronno-spisanie-plovdivski-istoriceski-forum [19 IX 2019].

Ramsay W.M., The Campaign of Basil I. against the Paulicians in 872 AD, "Classical Review" 10, 1896, p. 136-140.

The Regions of the World, trans. V. Minorsky, Oxford 1937.

Runciman S., The Medieval Manichee. A Study of the Christian Dualist Heresy, Cambridge 1947.

Sophoulis P., Byzantium and Bulgaria, 775-831, Leiden-Boston 2012.

Stoyanov Y., The Other God. Dualist Religions from Antiquity to the Cathar Heresy, New Haven 2000.

Tayyara A.R., Muslim-Paulician Encounters and Early Islamic Anti-Christian Polemical Writings, "Islam and Christian-Muslim Relations" 27, 4, 2016, p. 471-489, available online: http://www. tandfonline.com/10.1080/09596410.2016.1218 650 [19 IX 2019].

Ter-Mкrttschian K., Die Paulikianer im byzantinischen Kaiserreiche und verwandte ketzerische Erscheinunge in Armenien, Leipzig 1893.

Treadgold W., Photius Before His Patriarchate, "Journal of Ecclesiastical History" 53, 1, 2002, p. 1-17.

Tsibranska-Kostova M., Paulicians Between the Dogme and the Legend, "Studia Ceranea. Journal of the Waldemar Ceran Research Center for the History and Culture of the Mediterranean Area and South-Eastern Europe" 7, 2017, p. 229-263.

\begin{abstract}
Peter of Sicily, a Byzantine high official from the times of Basil I, intended to warn the Archbishop of Bulgaria against certain heretics, known as the Paulicians, as he learned during his mission to Tefrike about their plans of sending their missionaries there. His writings are regarded as the most competent source of information on the history and doctrine of the Paulicians. He also described some of their leaders, including Sergius himself.
\end{abstract}

According to Peter, it was a woman with whom Sergius had had an affair who made him the devil's tool. He accepted the name of Tychicos and passed himself off as a disciple of Paul the Apostle. For 34 years he was the leader of the Paulicians. Peter admits that Sergius was successful in winning followers and at the same time, besides making false statements, accuses him of selling Christians 
into slavery to barbarians and of collaboration with the Muslims. In the end, however, he was supposed to have an argument with another heresiarch, Baanes, which would lead to a break among the Paulicians.

Sergius is colourfully described as an enemy of the Cross, a voice of impiety, a lover of darkness and a wolf in sheep's clothing, who skilfully pretends to be a man of virtue but has deceived many. Although he himself was murdered in $834 / 835$, his work was continued by disciples of his.

Keywords: the Paulicians, Peter of Sicily, Sergius, heresy, Byzantine history.

Teresa Wolińska

University of Łódź

Faculty of Philosophy and History

Department of Byzantine History

ul. Kamińskiego 27a

90-219 Łódź, Poland

t.wolinska@wp.pl 